\title{
Investigating the Causes of Increased Twentieth-Century Fall Precipitation over the Southeastern United States
}

\author{
Daniel A. Bishop, ${ }^{\mathrm{a}, \mathrm{b}}$ A. PArk Williams, ${ }^{\mathrm{a}}$ Richard SeAger, ${ }^{\mathrm{a}}$ Arlene M. Fiore,,${ }^{\mathrm{a}, \mathrm{b}}$ \\ BENJAMIN I. COOK, ${ }^{\mathrm{a}, \mathrm{c}}$ Justin S. MANKIn, ${ }^{\mathrm{a}, \mathrm{c}, \mathrm{d}}$ DEEPTI Singh, ${ }^{\mathrm{a}, \mathrm{e}}$ JASON E. SMERDON, ${ }^{\mathrm{a}}$ \\ AND MUKUND P. RAO ${ }^{\mathrm{a}, \mathrm{b}}$ \\ ${ }^{a}$ Lamont-Doherty Earth Observatory, Columbia University, Palisades, New York \\ ${ }^{\mathrm{b}}$ Department of Earth and Environmental Sciences, Columbia University, New York, New York \\ ${ }^{\mathrm{c}}$ NASA Goddard Institute for Space Studies, New York, New York \\ ${ }^{\mathrm{d}}$ Department of Geography, Dartmouth College, Hanover, New Hampshire \\ ${ }^{\mathrm{e}}$ School of the Environment, Washington State University, Vancouver, Washington
}

(Manuscript received 23 April 2018, in final form 4 November 2018)

\begin{abstract}
Much of the eastern United States experienced increased precipitation over the twentieth century. Characterizing these trends and their causes is critical for assessing future hydroclimate risks. Here, U.S. precipitation trends are analyzed for 1895-2016, revealing that fall precipitation in the southeastern region north of the Gulf of Mexico (SE-Gulf) increased by nearly $40 \%$, primarily increasing after the mid-1900s. Because fall is the climatological dry season in the SE-Gulf and precipitation in other seasons changed insignificantly, the seasonal precipitation cycle diminished substantially. The increase in SE-Gulf fall precipitation was caused by increased southerly moisture transport from the Gulf of Mexico, which was almost entirely driven by stronger winds associated with enhanced anticyclonic circulation west of the North Atlantic subtropical high (NASH) and not by increases in specific humidity. Atmospheric models forced by observed SSTs and fully coupled models forced by historical anthropogenic forcing do not robustly simulate twentieth-century fall wetting in the SE-Gulf. SST-forced atmospheric models do simulate an intensified anticyclonic low-level circulation around the NASH, but the modeled intensification occurred farther west than observed. CMIP5 analyses suggest an increased likelihood of positive SE-Gulf fall precipitation trends given historical and future GHG forcing. Nevertheless, individual model simulations (both SST forced and fully coupled) only very rarely produce the observed magnitude of the SE-Gulf fall precipitation trend. Further research into model representation of the western ridge of the fall NASH is needed, which will help us to better predict whether twentieth-century increases in SE-Gulf fall precipitation will persist into the future.
\end{abstract}

\section{Introduction}

Hydroclimate variability has global impacts on water availability (Arnell 1999), food security (Schmidhuber and Tubiello 2007; Godfray et al. 2010), ecology and carbon sequestration (Zhu et al. 2016; Clark et al. 2016; D'Orangeville et al. 2018), and spatial extent and frequency of wildfires (Abatzoglou and Williams 2016; Westerling 2016). While the global area impacted by drought increased since the early to midtwentieth century, many regions experienced increased moisture availability, as expressed in soil moisture and drought indices, during this time because of increases in precipitation (Dai and

\footnotetext{
Corresponding author: Daniel A. Bishop, dbishop@ldeo.columbia. edu
}

Zhao 2017; Dai 2011, 2013; Sheffield et al. 2012; Qian et al. 2007). In much of the eastern United States in particular, annual precipitation increased significantly over the twentieth century (Hartmann et al. 2013; Seager et al. 2012; Pederson et al. 2013; Bishop and Pederson 2015; Easterling et al. 2017), increasing water availability for ecosystems and humans by enhancing runoff and evapotranspiration (Small et al. 2006; Qian et al. 2007). These precipitation increases were particularly strong in the fall season and since 1950 (Wang et al. 2009). The increases in fall precipitation were especially strong $(>50 \%$ or more over the past 120 years) throughout much of the southeastern United States (SEUS) (Williams et al. 2017; Easterling et al. 2017). The cause of these substantial increases in fall precipitation in the SEUS remains undiagnosed. 
Increases in SEUS precipitation may be partly driven by atmospheric responses to changes in sea surface temperature (SST), which can vary seasonally. Variability in tropical Pacific Ocean SSTs-El Niño-Southern Oscillation (ENSO) on interannual time scales and $\mathrm{Pa}-$ cific decadal variability on longer time scales-primarily influences the SEUS by increasing cold-season precipitation when SSTs in the tropical central and east Pacific are anomalously high (Dai et al. 1997; Mo 2010). During fall, the influence of ENSO on SEUS precipitation decreased substantially after 1960, despite exhibiting a strong influence before 1960 (Mo 2010). In the Atlantic Ocean, the North Atlantic Oscillation (NAO) impacts precipitation in the SEUS by altering North Atlantic storm tracks during the cold season but does not have much influence in fall (Hurrell 1995; Visbeck et al. 2001).

Prior to the transitional fall season, warm-season precipitation over the SEUS appears most strongly tied to the Atlantic multidecadal oscillation (AMO) via the strength and location of the North Atlantic subtropical high (NASH; also often referred to as the Bermuda high), which transports moisture into the region from the Gulf of Mexico and subtropical Atlantic Ocean (Enfield et al. 2001; Nigam et al. 2011; Shaw and Pauluis 2012; L. Li et al. 2012; Davis et al. 1997; Henderson and Vega 1996; Seager et al. 2014). When the AMO is positive and North Atlantic SSTs are warm, the NASH tends to be relatively weak and SEUS precipitation is suppressed as a result of reduced low-level moisture transport into the region (Kushnir et al. 2010; Weaver and Nigam 2008). Both historical and future changes in SEUS warm-season precipitation have been linked to changes in the NASH (L. Li et al. 2012; Li et al. 2011; Li et al. 2013; Li and Li 2015; W. Li et al. 2012; Diem 2013), in terms of its western ridge location as well as its intensity of central pressure (L. Li et al. 2012).

Despite extensive work to better understand the influence of SSTs on SEUS precipitation in the cold and warm seasons, much less research has been done to understand these teleconnection influences on SEUS precipitation in the fall season. Nigam et al. (2011) showed that the contribution of NASH variability, as calculated by AMO's impact on seasonal precipitation, is particularly strong in the fall, but the causes of the observed twentieth-century increases in fall precipitation in the SEUS are still undiagnosed.

In this study, we focus on the rarely studied fall season and investigate SEUS hydroclimatic trends and variability in terms of their timing, spatial extent, and physical origins. Focusing specifically on strong trends in the subregion of the SEUS north of the Gulf of Mexico that experienced the largest precipitation increases during the fall season, we explore dynamical connections to large-scale atmospheric circulation and moisture availability. We also evaluate atmosphere-only and fully coupled model simulations to assess the degree to which the observed fall wetting trend can be attributed to observed changes in SSTs and/or anthropogenic radiative forcing. Our analysis seeks to answer the following questions:

1) What are the characteristics of fall-season precipitation trends in the SEUS from 1895 to 2016 ?

2) What physical mechanism(s) caused increases in fallseason precipitation in the SEUS?

Answers to these questions are important for climate adaptation strategies, which should account for whether recent trends are expected to continue, amplify, or reverse.

\section{Methods}

\section{a. Data and study region}

Total monthly precipitation for 1895-2016 comes from the National Oceanic and Atmospheric Administration (NOAA) $(1 / 24)^{\circ}$ gridded Climgrid dataset (Vose et al. 2014; available at ftp://ftp.ncdc.noaa.gov/ pub/data/climgrid). To characterize the uncertainty in observed trends, we also use monthly precipitation totals for 1901-2016 (the period of common overlap among observational products and models) from the Global Precipitation Climatology Centre (GPCC) Full Data Reanalysis, version 2018 (referred to as GPCC herein; Schneider et al. 2018; ftp://ftp.dwd.de/pub/data/ gpcc/html/fulldata-monthly_v2018_doi_download.html), Parameter-Elevation Regressions on Independent Slopes Model (PRISM; Daly et al. 2008; http://www.prism. oregonstate.edu), Climate Research Unit TS4.01 (CRU; Harris et al. 2014; https://crudata.uea.ac.uk/cru/data/hrg), and the U.S. subset of the Global Historical Climatology Network, version 3.23 (GHCN; Menne et al. 2012, 2009; https://www.ncdc.noaa.gov/ghcn-daily-description). For comparison, all gridded precipitation products were bilinearly interpolated to a common $1 / 8^{\circ} \times 1 / 8^{\circ}$ grid. For GHCN, weather stations are considered if, for at least 75 years for the period 1895-2016, each fall month (September-November) had valid precipitation totals for at least $75 \%$ of daily precipitation observations. Missing daily precipitation values were replaced by the mean daily precipitation total from the month and precipitation totals during the fall season were calculated for each station containing all three months of valid precipitation data. These records were converted to the fraction of the mean during a baseline period of 1951-90 (when station density was relatively high). 


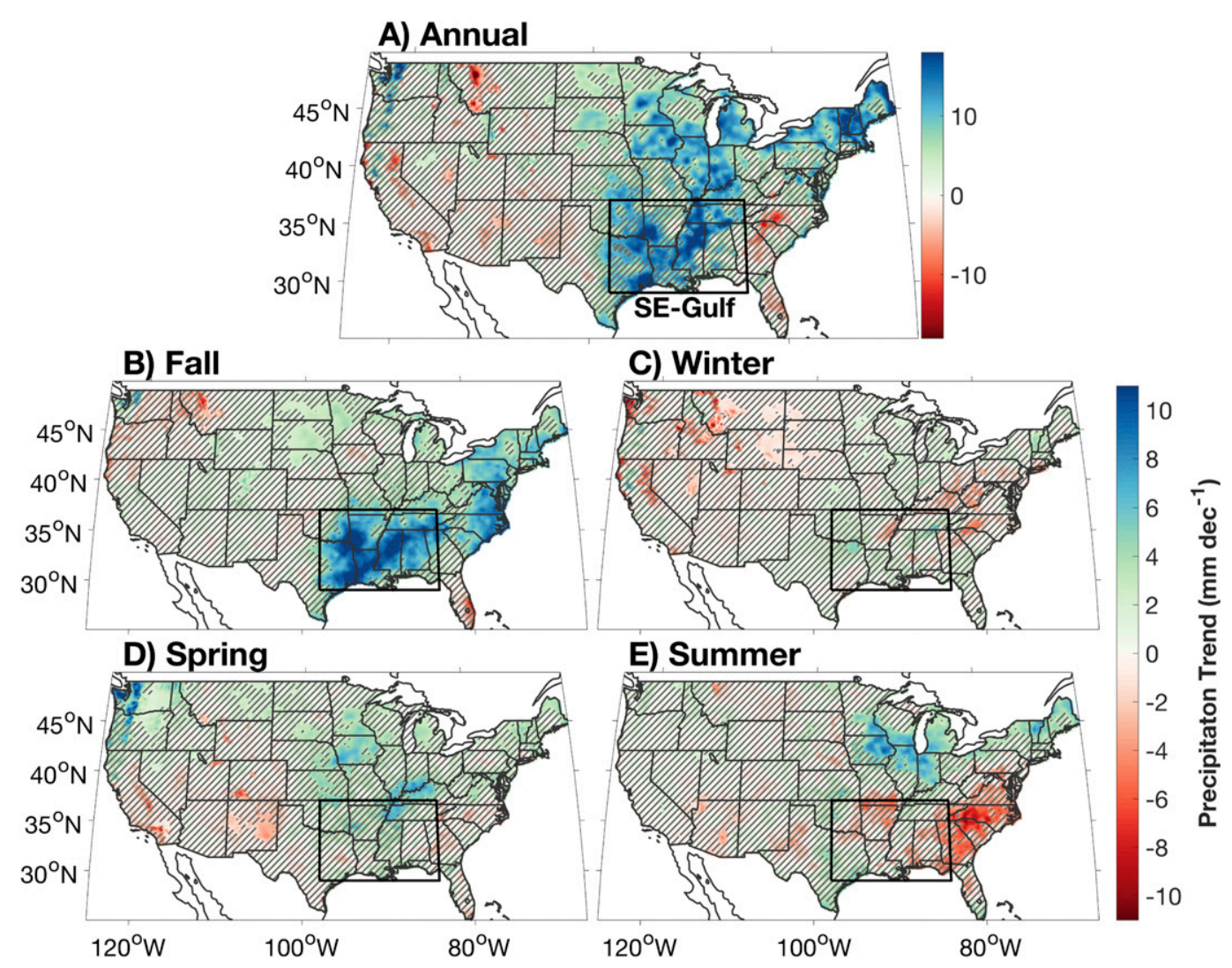

FIG. 1. NOAA Climgrid total precipitation trends (1895-2016) over the contiguous United States for (a) annual, (b) fall, (c) winter, (d) spring, and (e) summer. The boxed area represents the selected hydroclimate region across the SEUS north of the Gulf of Mexico (SE-Gulf). Crosshatching indicates insignificant $(p>0.05)$ trends using a standard two-sided $t$ test.

Stations with more than 10 missing years of data during this baseline period were dismissed. Of all stations, 125 stations meet these criteria. To avoid biasing the regional mean toward areas with high station density, records were gridded by averaging across all station records within each $2^{\circ} \times 2^{\circ}$ box and land area-weighted regional means were computed from these gridded records. The resultant regional record of fraction of mean precipitation was converted back to precipitation totals by multiplying by the NOAA Climgrid 1951-90 regionally averaged fall precipitation total.

To evaluate large-scale atmospheric circulation for 1948-2016, we use National Centers for Environmental Prediction-National Center for Atmospheric Research (NCEP-NCAR) reanalysis data (Kalnay et al. 1996; https://www.esrl.noaa.gov/psd/data/gridded/data.ncep. reanalysis.html). We calculated linear least squares trends in seasonal Climgrid, GPCC, PRISM, CRU, and GHCN precipitation for 1895-2016 (1901-2016 for CRU), and NCEP-NCAR circulation and pressure variables (sea level pressure, geopotential height, moisture flux) for 1948-2016.
We define our study region as the "Southeast United States-Gulf of Mexico" (SE-Gulf), a geographic box immediately north of the Gulf of Mexico $\left(29^{\circ}-37^{\circ} \mathrm{N}\right.$, $98^{\circ}-84^{\circ} \mathrm{W}$; see Fig. 1). This region was chosen because it bounds the largest and most significant wetting trends in the contiguous United States.

\section{b. Moisture transport mechanisms and dynamics}

To investigate relationships between SE-Gulf precipitation and large-scale atmospheric circulation, we evaluated 6-hourly vertically integrated moisture flux [Eq. (1)] in NCEP-NCAR between the surface and $700 \mathrm{hPa}$ (exploratory analysis identified moisture transports in this layer as the most highly correlated with SEGulf precipitation):

$$
\text { Total moisture flux }=g^{-1} \int_{\text {Surface }}^{700 \mathrm{hPa}} q \mathbf{v} d p
$$

where $\mathbf{v}$ is the wind vector at each pressure level $\left(\mathrm{m} \mathrm{s}^{-1}\right)$, $q$ is specific humidity $\left(\mathrm{kg} \mathrm{kg}^{-1}\right), p$ is pressure $(\mathrm{Pa})$, and $g$ is the gravitational acceleration $\left(\mathrm{m} \mathrm{s}^{-2}\right)$. 
We further disaggregated the NCEP-NCAR moisture flux variability into components driven by variations in wind [Eq. (2a)] or humidity [Eq. (2b)] by recalculating moisture flux for each component while holding the other component at its monthly climatology:

$$
\text { Wind-driven moisture flux }=g^{-1} \int_{\text {Surface }}^{700 \mathrm{hPa}} \bar{q} \mathbf{v} d p \text { and }
$$

$$
\text { Humidity-driven flux }=g^{-1} \int_{\text {Surface }}^{700 \mathrm{hPa}} q \overline{\mathbf{v}} d p
$$

where overbars indicate 1948-2016 climatological monthly means for each grid cell and pressure level. While calculations of moisture flux at the 6-hourly interval include contributions from both the monthly mean state and transient eddies, trends and variations relevant to the SEGulf are dominated by the monthly mean state with only minor contributions from transient eddies.

\section{c. Model representation of precipitation trends}

Prior work has shown that some observed regional precipitation trends and anomalies over North America can be accurately simulated by atmospheric models when forced by observed global SSTs, suggesting that these historical features were to a large extent forced by SST variations (Seager et al. 2005). To test for the possible role of SSTs as drivers of fall wetting in the SE-Gulf, we evaluated trends in fall precipitation simulated by the following two atmospheric models when forced with observed SSTs from 1901 to 2015: the NCAR Community Climate Model, version 3 (CCM3; Kiehl et al. 1998), and the NCAR Community Atmosphere Model, version 5 (CAM5; Neale et al. 2012). Each model was run 16 times (16 ensemble members). In our examination of model performance in the SE-Gulf, we found that the CCM3 and CAM5 simulations are physically consistent and capture the salient features of the observed SE-Gulf monthly precipitation annual cycle. However, the overall magnitude of SE-Gulf climatological annual and fall mean precipitation simulated is too low in both models, $\sim 30 \%$ of observed for CCM3 and $\sim 50 \%$ of observed for CAM5 (not shown). $\mathrm{CCM} 3$ was run at an approximately $2.8^{\circ} \times 2.8^{\circ}$ resolution with 18 vertical levels, with an SST forcing from Kaplan et al. (1998) from 1856 to 1870 globally and 1856 to 2009 inside the tropics $\left(20^{\circ} \mathrm{N}-20^{\circ} \mathrm{S}\right)$, and Met Office Hadley Centre SSTs (Rayner et al. 2003) from 1871 to 2009 outside the tropics and from 2009 to 2015 globally. CAM5 was run at an approximately $2.8^{\circ} \times 2.8^{\circ}$ resolution with 30 vertical levels, with an SST forcing globally from Hadley Centre SSTs from 1856 to 2015. More details on these simulations can be found in Seager et al. $(2014,2015)$.
Trends in SE-Gulf fall precipitation were also calculated from 1901 to 2005 in a 43-model ensemble of phase five of the Coupled Model Intercomparison Project (CMIP5; Taylor et al. 2012; data available at https:/lesgfnode.llnl.gov/search/cmip5) historical simulations (historical, aerosol-only, greenhouse gas-only, and natural-only forcing). To evaluate possible effects of anthropogenic radiative forcing that may act in addition to, or independent of, effects driven by observed SSTs, projected trends from 2006 to 2099 were also calculated for CMIP5 simulations using the representative concentration pathway 8.5 (RCP8.5; Riahi et al. 2011). The RCP8.5 scenario represents the pathway with a relatively high level of future radiative forcing from greenhouse gas emissions (van Vuuren et al. 2011). This scenario was chosen specifically to identify the modeled response to strong anthropogenic forcing on SE-Gulf precipitation. In examining model performance, we found that the CMIP5 models generally capture the observed SE-Gulf mean annual cycle of precipitation. Further, the CMIP5 simulations do not have a consistently low precipitation bias (as found in the SST-forced models; not shown), suggesting that ocean-atmosphere coupling may be important for accurately simulating SE-Gulf precipitation. All modeled precipitation fields were interpolated to a common $1 / 8^{\circ} \times 1 / 8^{\circ}$ grid using bilinear interpolation before regional land area-weighted averages are computed. Table 1 lists the CMIP5 ensembles used in this study.

To evaluate the likelihood of the observed fall precipitation trend in a modeling framework, we calculated linear trends in simulated SE-Gulf fall precipitation for all 115-yr moving-window periods during 1856-2015 for the SST-forced models and all 105-yr moving-window periods during 1850-2005 for the CMIP5 historical simulations. For SST-forced models, moving-window trends were recomputed after subtracting each model's ensemble-mean time series to evaluate trends due to internal atmospheric variability unforced by SSTs (e.g., Deser et al. 2012). Given the limited 16-member ensemble size of CCM3 and CAM5, this approach does not capture the full range of atmospheric variability, but it nonetheless provides insight as to whether trends as large as those observed are likely to arise as a result of unforced atmospheric variability alone. Modeled trends were compared with observed SE-Gulf fall precipitation trends during 1901-2005 and 1901-2015, computed from the five observational products (Climgrid, GPCC, PRISM, CRU, and the U.S. subset of the GHCN).

Last, to evaluate model ability to simulate observed trends in the NASH, we calculated linear trends in sea level pressure and 850-hPa winds for CCM3, CAM5, and CMIP5 historical simulations during the common period of overlap with the NCEP-NCAR reanalysis (1948-2005). 
TABLE 1. List of CMIP5 models (expansions can be found at https://www.ametsoc.org/PubsAcronymList) and number of runs used: "historical" simulations are forced by observed changes in atmospheric composition reflecting both anthropogenic and natural sources during the industrial period (1850-2005), "RCP8.5" uses the highest forecast GHG emission scenario leading to a radiative forcing of $8.5 \mathrm{~W} \mathrm{~m}^{-2}$ by the end of the twenty-first century (2006-99), "aerosol" are historical simulations with aerosol forcing only, "GHG" are historical simulations with GHG forcing only, and "natural" are historical simulations with natural forcings only (Taylor et al. 2012; Riahi et al. 2011).

\begin{tabular}{|c|c|c|c|c|c|}
\hline Models & Historical & RCP8.5 & Aerosol & GHG & Natural \\
\hline ACCESS1.0 & 1 & 1 & - & - & - \\
\hline ACCESS1.3 & 1 & 1 & - & 1 & 3 \\
\hline BCC_CSM1.1 & 3 & 1 & - & 1 & 1 \\
\hline BCC_CSM1.1(m) & 3 & 1 & - & - & - \\
\hline BNU-ESM & 1 & 1 & - & 1 & 1 \\
\hline CanESM2 & 5 & 5 & 5 & 5 & 5 \\
\hline CCSM4 & 6 & 6 & 6 & 3 & 4 \\
\hline CESM1(BGC) & 1 & 1 & - & - & - \\
\hline CESM1(CAM5) & 3 & 3 & 3 & 3 & 3 \\
\hline CESM1(CAM5)-1-FV2 & 4 & 1 & - & - & - \\
\hline CESM1(WACCM) & 4 & 3 & - & - & - \\
\hline CMCC-CESM & 1 & 1 & - & - & - \\
\hline CMCC-CM & 1 & 1 & - & - & - \\
\hline CMCC-CMS & 1 & 1 & - & - & - \\
\hline CNRM-CM5 & 10 & 5 & - & 6 & 6 \\
\hline CSIRO Mk3.6.0 & 10 & 10 & 5 & 5 & 5 \\
\hline EC-EARTH & 1 & 1 & - & - & - \\
\hline FGOALS-g2 & 5 & 1 & 1 & 1 & 3 \\
\hline FGOALS-s2 & 3 & 3 & - & - & - \\
\hline FIO-ESM & 3 & 3 & - & - & - \\
\hline GFDL CM3 & 5 & 1 & 3 & 3 & 3 \\
\hline GFDL-ESM2G & 3 & 1 & - & - & - \\
\hline GFDL-ESM2M & 1 & 1 & 1 & 1 & 1 \\
\hline GISS-E2-H & 11 & 4 & 10 & 5 & 10 \\
\hline GISS-E2-H-CC & 1 & 1 & - & - & - \\
\hline GISS-E2-R & 16 & 4 & 10 & 5 & 10 \\
\hline GISS-E2-R-CC & 1 & 1 & - & - & - \\
\hline HadGEM2-AO & 1 & 1 & - & - & - \\
\hline HadGEM2-CC & 3 & 3 & - & - & - \\
\hline HadGEM2-ES & 4 & 4 & - & 4 & 4 \\
\hline INM-CM4.0 & 1 & 1 & - & - & - \\
\hline IPSL-CM5A-LR & 6 & 4 & 1 & 6 & 3 \\
\hline IPSL-CM5A-MR & 3 & 1 & - & 3 & 3 \\
\hline IPSL-CM5B-LR & 1 & 1 & - & - & - \\
\hline MIROC-ESM & 3 & 1 & - & 3 & 3 \\
\hline MIROC-ESM-CHEM & 1 & 1 & - & 1 & 1 \\
\hline MIROC5 & 5 & 3 & - & - & - \\
\hline MPI-ESM-LR & 3 & 3 & - & - & - \\
\hline MPI-ESM-MR & 3 & 1 & - & - & - \\
\hline MRI-CGCM3 & 5 & 1 & - & 1 & 1 \\
\hline MRI-ESM1 & 1 & 1 & - & - & - \\
\hline NorESM1-M & 3 & 1 & 1 & 1 & 1 \\
\hline NorESM1-ME & 1 & 1 & - & - & - \\
\hline Total & 149 & 91 & 46 & 59 & 71 \\
\hline
\end{tabular}

\section{Results}

\section{a. Precipitation trends}

According to NOAA Climgrid, $22 \%$ of the contiguous United States experienced significant (significance level $p<0.05)$ positive trends in total annual precipitation during 1895-2016, with the vast majority of these positive trends occurring in the eastern United States
(Fig. 1a). Seasonally, the largest wetting trends occurred in fall, mainly in the SEUS and mid-Atlantic coast (Fig. 1b). In the SE-Gulf region, mean fall precipitation increased by $37 \%(87 \mathrm{~mm})$, far outpacing changes in other seasons or regions, consistent with Easterling et al. (2017). The $87-\mathrm{mm}$ increase in fall precipitation accounted for $74 \%$ of the annual trend during 1895-2016. In summer (June-August), significant but less substantial 


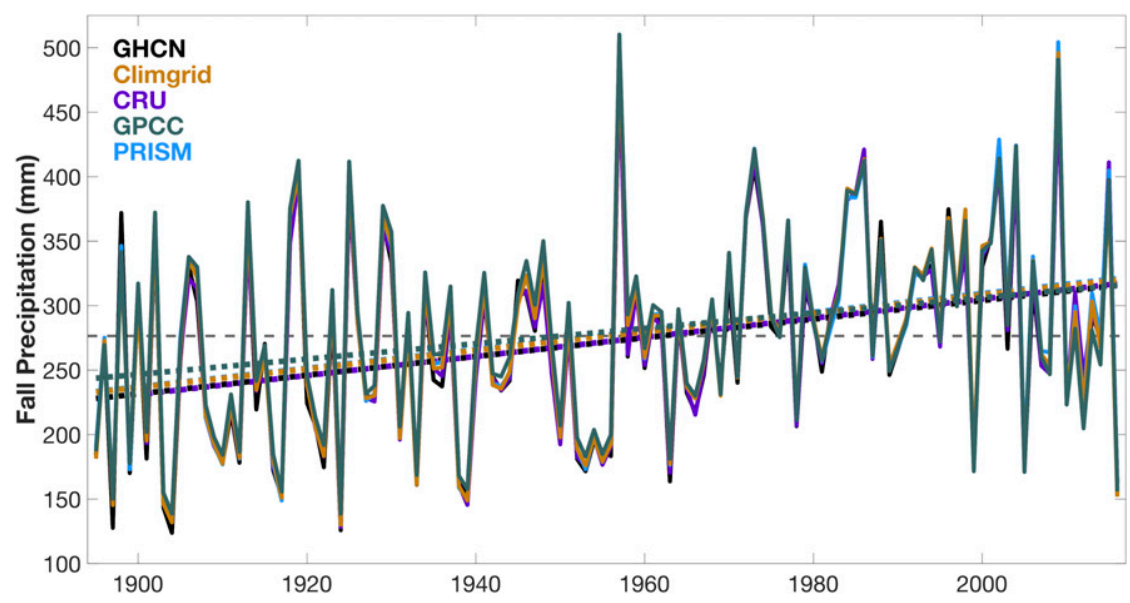

FIG. 2. SE-Gulf mean fall precipitation from GHCN, Climgrid, CRU, GPCC, and PRISM. Coverage is 1895-2016 for GHCN, PRISM, GPCC, and Climgrid and 1901-2016 for CRU. Dotted lines represent linear trends; the horizontal dashed line represents mean Climgrid fall precipitation for 1895-2016.

increases in precipitation were observed over parts of the Midwest and northern New England. In winter (DecemberFebruary) and spring (March-May), there was far less spatial coherence in trends (Figs. 1c-e).

All five of the employed precipitation datasets correlated strongly (correlation coefficient $r>0.99$ ) with the Climgrid record of SE-Gulf fall precipitation and agreed on significant positive trends (Fig. 2). During their 1901-2016 common period, linear increases were between 83 and $85 \mathrm{~mm}$ for Climgrid, PRISM, CRU, and GHCN, and $67 \mathrm{~mm}$ for GPCC. The GPCC trend was within the $95 \%$ range of uncertainty surrounding trends calculated from the other products. The strong interannual relationship among time series indicates that trend differences arise from minor differences in the precipitation time series. Notably, the fall precipitation increase calculated from the GHCN station data exceeded $80 \mathrm{~mm}$ even when calculated from only the longest, unaltered station records (with data for $95 \%$ of years during 1895-2016), lending more confidence to the Climgrid trend than the smaller GPCC trend. Given these findings, we use Climgrid fall precipitation in all remaining observational analyses.

Although climate trends are often assessed as linear changes, we find with a nonparametric Pettitt's test for changepoints (Pettitt 1979; Villarini et al. 2009) that the fall wetting trend in the SE-Gulf could also be described as a mean shift toward wetter conditions in the mid1950s. The mean shift was statistically significant based on a bootstrapped, phase-randomization approach in which random time series were produced while preserving the observed autocorrelation structure and spectral power (for methods, see Coats et al. 2016;
Schreiber and Schmitz 2000). Further, mean-square error is lower when the precipitation increase is assessed as a step increase following 1956 rather than a linear trend.

\section{b. Dynamical drivers of enhanced fall precipitation in the SE-Gulf region}

Fall precipitation in the SE-Gulf region was positively correlated with fall upper-tropospheric geopotential heights $(200 \mathrm{hPa})$ over the western Atlantic and sea level pressure (SLP) over the subtropical and tropical Atlantic and negatively correlated with uppertropospheric geopotential heights and SLP over the western United States (Figs. 3a,b). These interannual correlation patterns indicate that higher SE-Gulf precipitation was associated with a wave pattern that involved upper-troposphere southwesterly flow over the SE-Gulf. These observations were further linked to southerly low-level moisture flux into the region from the Gulf of Mexico along the western flank of the $\mathrm{NASH}$, indicating that an anomalously strong NASH is related to high fall precipitation in the SE-Gulf (Fig. 3c).

To further investigate the drivers of variability and increases in SE-Gulf precipitation, we regressed fall SEGulf precipitation against mean fall meridional surface$700 \mathrm{hPa}$ moisture flux from the Gulf of Mexico into the SE-Gulf (within the box $29^{\circ}-21^{\circ} \mathrm{N}, 98^{\circ}-84^{\circ} \mathrm{W}$ ) in the NCEP-NCAR reanalysis. This measure of meridional moisture flux captured $61 \%$ (unadjusted $\mathrm{R}^{2}$ ) of the observed variance in SE-Gulf fall precipitation, indicating that NCEP-NCAR meridional moisture flux represents interannual variability in SE-Gulf fall precipitation quite well. Southerly moisture flux from the Gulf of 


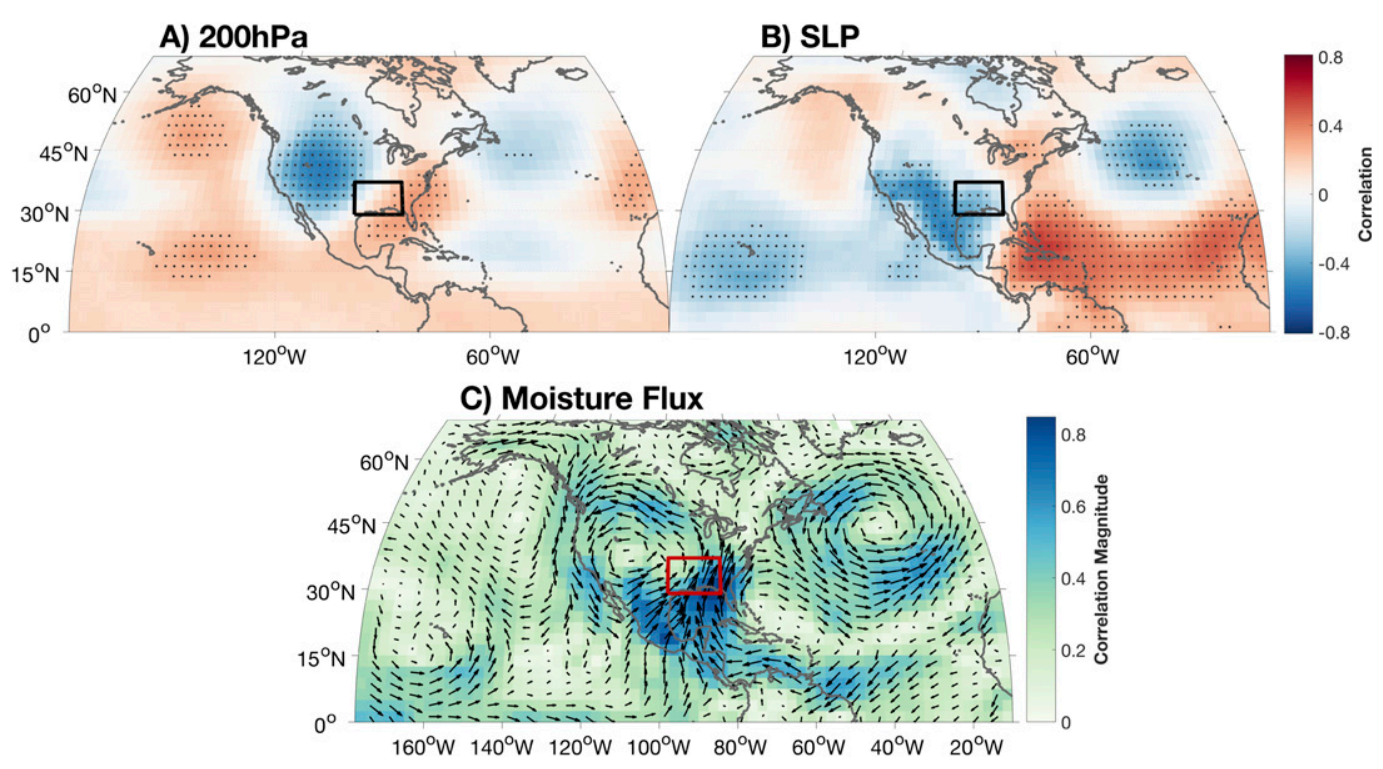

FIG. 3. Spearman's rank correlation (1948-2016) between SE-Gulf fall precipitation and (a) 200-hPa geopotential height, (b) SLP, and (c) vertically integrated (from sea level to $700 \mathrm{hPa}$ ) moisture flux (colors = magnitude, arrows $=$ direction and magnitude) from the NCEP-NCAR reanalysis. Dots in (a) and (b) indicate significant $(p<0.05)$ correlation coefficients. In $(c)$, all correlation vectors are shown as black arrows to aid interpretability of the circulation patterns, while the correlation magnitude is also shown and is calculated as the square root of the sum of squared correlations for the meridional and zonal directions. Black [in (a) and (b)] and red [in (c)] boxes bound the SE-Gulf region. The maximum-length arrow vector in a horizontal or vertical direction represents a correlation magnitude of 0.85 .

Mexico also increased significantly from 1948 to 2016. Applying the linear regression coefficients calculated for the relationship between SE-Gulf precipitation and meridional moisture flux, the increase in NCEP-NCAR southerly moisture flux explains $94 \%$ of the observed increase in SE-Gulf precipitation during 1948-2016. Decomposing the moisture flux trend into contributions from wind versus humidity [as formulated in Eqs. (1) and $(2 \mathrm{a}, \mathrm{b})], 81 \%$ of the observed precipitation trend during 1948-2016 was due to increased southerly wind velocity, only $2 \%$ was due to increased specific humidity, and the remaining $11 \%$ of the $94 \%$ moisture flux contribution was due to interaction between specific humidity and wind velocity (Fig. 4).

That the positive trend in fall-season SE-Gulf precipitation was likely associated with wind-driven increases in moisture transport, rather than increased specific humidity, suggests the increase in SE-Gulf precipitation was associated with large-scale circulation changes. NCEP-NCAR indeed indicates that fall trends in meridional moisture flux over the Gulf of Mexico were closely associated with large-scale increases in wind velocity along the western portion of the NASH (Figs. 5a,b), which consistently promoted increases in SE-Gulf fall precipitation (Fig. 3). Furthermore, SLP increases over the Caribbean, perhaps linked to NASH intensification and/or changes in NASH position, indicate intensification in anticyclonic circulation around the western ridge of the NASH (Fig. 5c). These trends for the fall season are similar to the summer trends in the western ridge of the NASH reported in Li et al. (2011).

\section{c. Model representations of fall precipitation trends}

Can climate models reproduce trends as strong as those observed? The two SST-forced atmospheric models (CCM3 and CAM5) did not simulate large increases in ensemble-mean fall precipitation in the SEGulf region during 1901-2015, but they did simulate large positive trends farther west over northwestern Mexico (Figs. 6a,b). In addition to the ensemble-mean responses, individual ensemble members (which contain internal atmospheric variability) also did not produce increases in SE-Gulf fall precipitation as large as observed. Only two CAM5 ensemble member trends were within the uncertainty range from GPCC (Fig. 6c). Notably, both SST-forced models did accurately simulate the interannual response of SE-Gulf fall precipitation to global SSTs and atmospheric circulation around the NASH quite well, suggesting these SST-forced models did not simulate the observed increase in southerly lowlevel circulation into the SE-Gulf around the western edge of the NASH (not shown). 

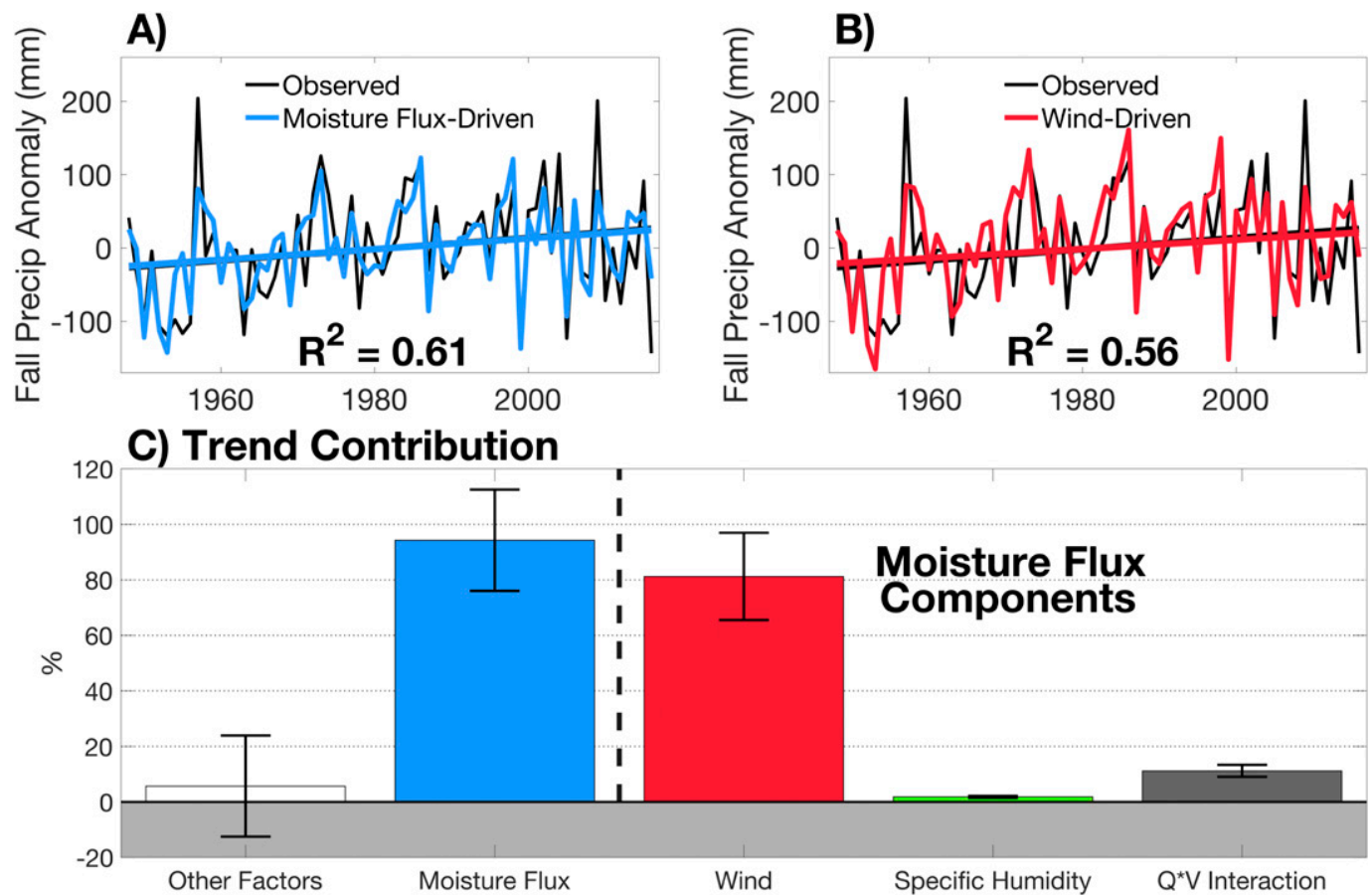

FIG. 4. Drivers of the increase in SE-Gulf fall precipitation from 1948 to 2016: Linear estimates of precipitation anomalies based on (a) Gulf of Mexico meridional surface- $700 \mathrm{hPa}$ moisture flux (blue) and (b) wind-driven meridional moisture flux (red) with observed NOAA Climgrid fall precipitation anomalies (black). (c) Percent contributions to the observed trend from unaccounted factors (white), Gulf of Mexico meridional moisture flux (blue) and wind-driven moisture flux (pink), specific humidity-driven moisture flux (green), and the residual interaction between specific humidity and wind (gray). Whiskers bound $95 \%$ confidence intervals of each trend contribution derived from the predicted regression coefficients for fall precipitation.

The ensemble average of the 43 members in the CMIP5 historical simulations, simulations that include fully coupled feedbacks between the ocean, land, and atmosphere, did indicate a slight positive trend in SE-Gulf fall precipitation during the historical simulation period of 19012005 (Fig. 7a). This positive trend appears to be primarily due to greenhouse forcing for two reasons. First, the ensemble-mean trend in the greenhouse gas (GHG)-only simulations was more positive than trends in the aerosolonly and natural-only simulations. Second, the ensemblemean trend in RCP8.5 future simulations (2006-99) was more positive than that for the historical scenario (Figs. 7b,c). However, there was little agreement within each historical and future ensemble as to the sign and magnitude of simulated trends (Fig. 7c). Among all 325 historical runs, 2 (both from the CSIRO MK3.6.0 model's GHG-only simulations) simulated trends approximately equal to the GPCC-observed trend and several more simulated trends within the GPCC confidence interval, but none matched the trends from any of the other four observational datasets. Last, simulations forced with the relatively aggressive RCP8.5 future emissions scenario still predominantly simulated trends smaller than those observed, but more positive than those from historical simulations (Fig. 7c). Like the SST-forced models, the CMIP5 models simulated the relationship between SEGulf fall precipitation and the NASH quite well. However, unlike the SST-forced atmospheric models, CMIP5 simulations did not consistently capture the observed global pattern of correlation between SE-Gulf fall precipitation and SSTs (not shown), raising questions as to their ability to accurately capture the coupling between the ocean and atmospheric circulation variations that drive SE-Gulf fall precipitation.

Analyses of SST-forced and historical CMIP5 simulations suggest a near inability of models to simulate observed SE-Gulf fall precipitation trends when forced by observed SSTs or external forcings despite including internal variability. We further evaluate this using a moving-window trend analysis across the full duration of all SST-forced and CMIP5 historical simulations (which all began in the mid-1800s) of SE-Gulf fall precipitation. This moving-window analysis gives each model simulation more chances to register a trend as strong as that observed, allowing for a more thorough sampling of the distribution of possible modeled trends under historical conditions.

Figure 8 shows the largest trend achieved by each model simulation. Among SST-forced simulations (Fig. 8a; red 


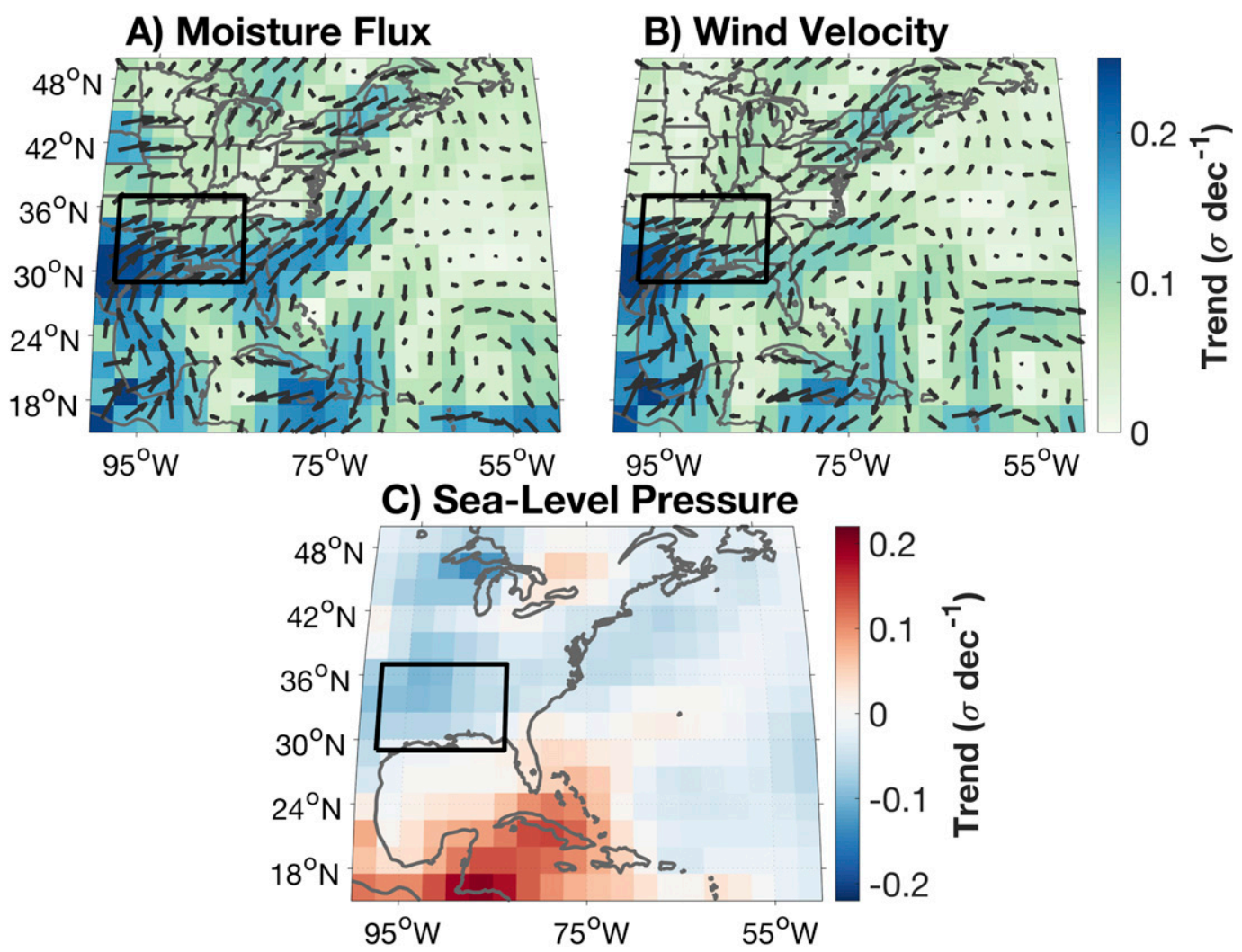

FIG. 5. NCEP-NCAR (1948-2016) reanalysis fall trends in standardized (a) vertically integrated (surface$700 \mathrm{hPa}$ ) moisture flux, (b) wind velocity, and (c) SLP. Colors indicate trend magnitude; arrows indicate direction and magnitude of trend [in (a) and (b)]. The black box bounds the SE-Gulf region.

dots), zero ensemble members produced 115-yr trends as strong as observed from 1901 to 2015, although occasional (one from CCM3 and two from CAM5) simulations had at least one 115-yr trend that was within the GPCC confidence interval. Interestingly, the distribution of simulated trends widened and the maximum trends increased when we subtracted away each model's SST-forced ensemble mean, thereby approximating the ability of internal atmospheric variability alone to produce a simulated trend as strong as that observed (Fig. 8a; blue dots). Among these atmosphere-only simulated precipitation records, one (from CCM3) included a 115-yr period that matched or exceeded all observed trends and one additional trend from each model exceeded the GPCC trend. Additionally, nine trends from CCM3 and four trends from CAM5 were within the GPCC confidence interval. This suggests that long-term SST trends actually reduced the chances of strong increases in SE-Gulf precipitation and that, while extremely improbable, the observed trend could have conceivably arisen without SST forcing.

Among the 325 CMIP5 historical model runs, including aerosol-, GHG-, and natural-only simulations, 6 contained at least one 105 -yr trend magnitude as large as or larger than the observed 1901-2005 GPCC trend and only one simulated trend (from CanESM2) exceeded all observed trends (Fig. 8b). Thirteen percent of CMIP5 historical simulations contained a trend that was within the GPCC confidence interval.

Given the near inability of models to simulate observed SE-Gulf fall precipitation trends, but their ability to simulate observed SE-Gulf fall precipitation sensitivity to circulation around the NASH, we compared modeled fall trends in low-level atmospheric circulation to those represented by the NCEP-NCAR reanalysis during 1948-2005. As discussed earlier, NCEP-NCAR shows increased SLP on the southwest side of the NASH and decreased SLP over southwestern North America, which increased the zonal pressure gradient over the Gulf of Mexico and enhanced southerly circulation into the SEUS (Fig. 9a). Interestingly, both SST-forced models also indicate increased SLP and intensified circulation around the west side of the NASH, but these simulated trends occur too far west, driving increased precipitation in northwestern Mexico instead of the SE-Gulf (Figs. 9b,c). Circulation trends were much weaker in the CMIP5 ensemble mean (Fig. 9d) but nevertheless 

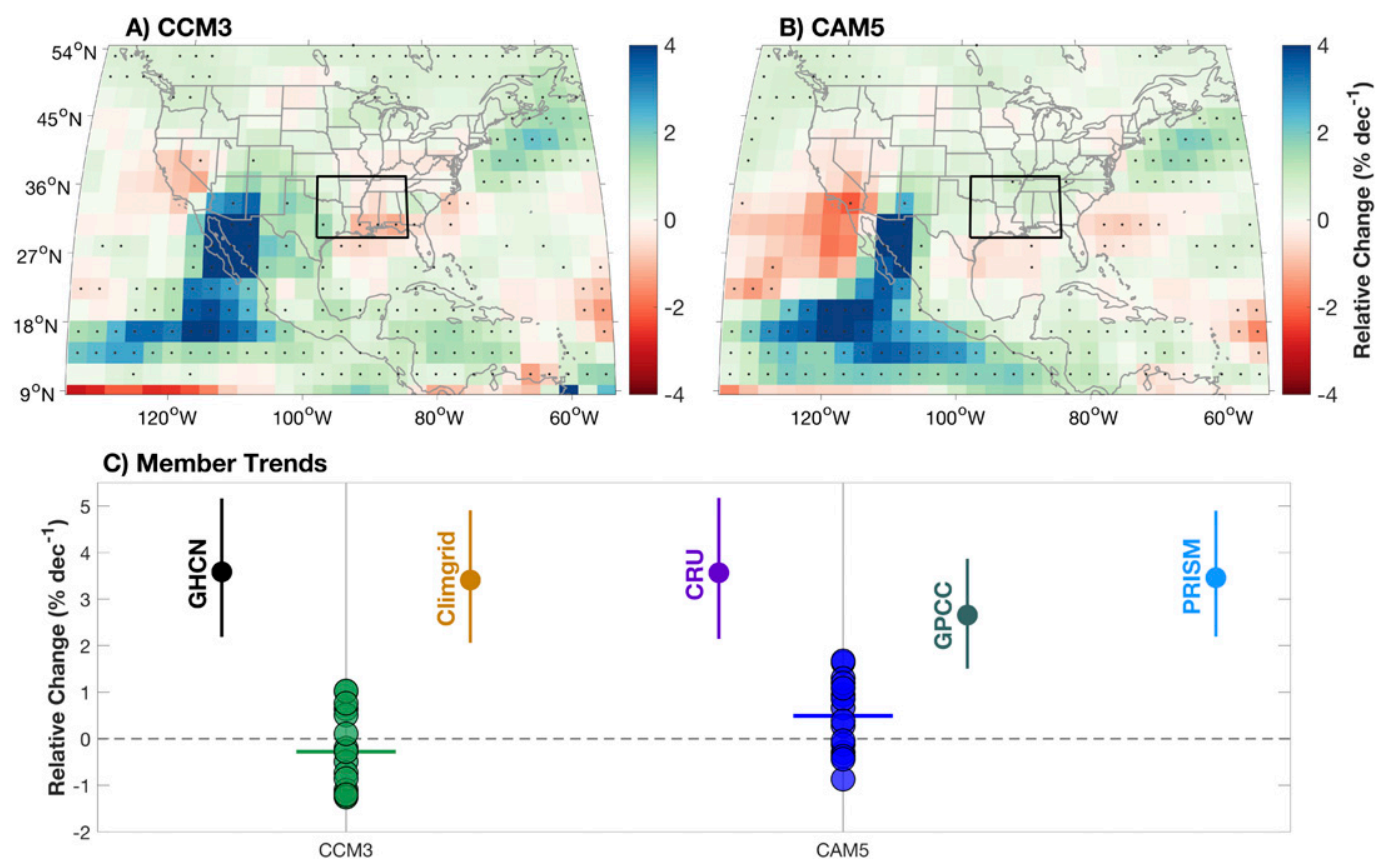

FIG. 6. Ensemble-mean relative change (1901-2015) in fall precipitation for (a) CCM3 (16 members) and (b) CAM5 (16 members), and (c) relative change for individual member runs with CCM3 and CAM5 simulations, including 1901-2015 observed GHCN, Climgrid, CRU, GPCC, and PRISM relative change for reference. In (a) and (b), map colors indicate relative percent change per decade calculated with linear regression and dots indicate grid cells where greater than $75 \%$ of model simulations agree on the sign of the change. Vertical colored lines in (c) indicate $95 \%$ confidence intervals for observed linear trends from 12-yr block bootstrapping, and horizontal colored lines indicate ensemble means of simulated change.

suggest a slight anthropogenic enhancement of the western ridge of the NASH. These trends strengthened in future RCP8.5 projections (not shown). All reanalysis and model-ensemble-mean SLP trends suggest a southward shift or expansion in the western ridge of the fall NASH from its climatological mean over the coastal mid-Atlantic toward southern Florida and the Caribbean Sea.

\section{Discussion}

Large increases in annual precipitation have been observed over the past century across much of the SEUS. These increases are mostly due to trends in the fall season, particularly in the SE-Gulf region, where fall precipitation increased by nearly $40 \%$ during $1895-$ 2016. This increase appears to have predominantly occurred as a shift in the midtwentieth century, from a climate with regular occurrence of severe drought events to one with a greatly reduced drought frequency (Williams et al. 2017).

In contrast, there was little to no trend in SE-Gulf precipitation during spring, summer, and winter. Consequently, the large increase in fall precipitation has substantially dampened the seasonality of precipitation, because fall is the climatological dry season for the region. Whether the observed twentieth-century trend in fall precipitation will endure into the future, intensify, or reverse course has the potential to greatly impact human and natural systems in the region. Should fall precipitation decline in the future, or should extreme droughts such as those that occurred in 2016 become more frequent, the most vulnerable human and ecological systems may be those that have developed or adapted to relatively wet conditions and a muted dry season during the past 60 years (Williams et al. 2017).

The twentieth-century increases in SE-Gulf fall precipitation were due to increases in southerly moisture transport into the region from the Gulf of Mexico and Caribbean. These increases in southerly moisture transport were driven almost entirely by increases in southerly wind flow rather than an increase in specific humidity, consistent with prior work suggesting that variability in summer moisture flux into the SEUS is primarily driven by dynamic processes (Li et al. 2013). Increased southerly wind flow into the SEUS was associated with enhanced anticyclonic circulation around the western boundary of the NASH. Importantly, these results are based on the NCEP-NCAR reanalysis, which is not a true observational product. However, the correlation between 

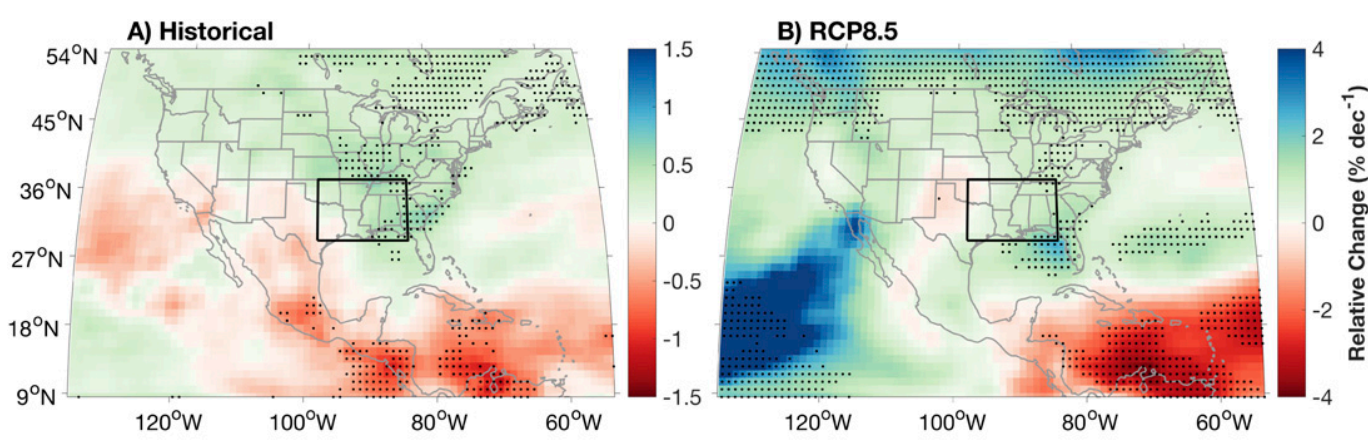

C) CMIP5 Member Trends
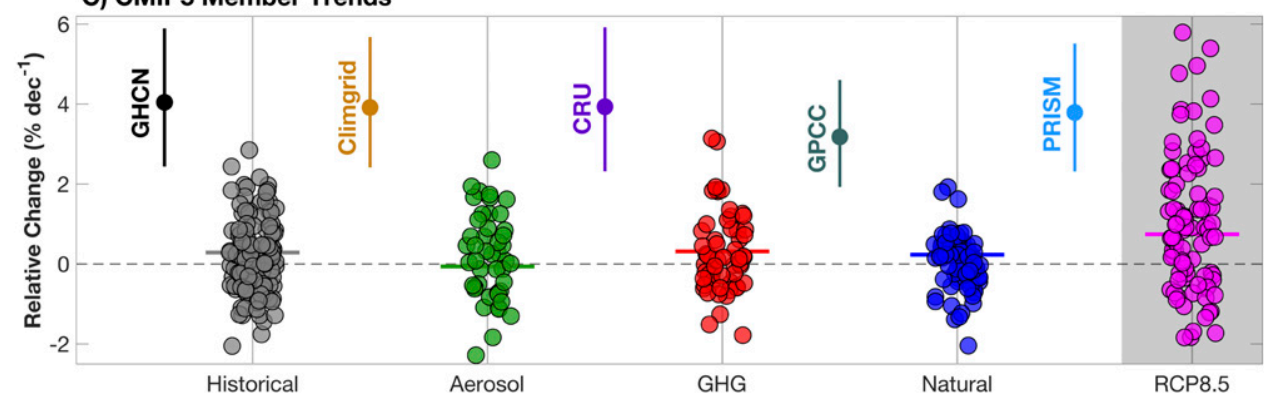

FIG. 7. CMIP5 fall-season precipitation trends (relative linear change per decade). Maps show trends in ensemble means for (a) historical (1901-2005) and (b) RCP8.5 (2006-99) radiative forcing scenarios. These ensemble means are based on the 43 models for which monthly precipitation data were available for both scenarios. (c) Swarm plots show trends in ensemble means (horizontal lines; colored by simulation type) and each individual model simulation (dots; colored by simulation type) for the SE-Gulf region for multiple CMIP5 experiments: historical, historical aerosol only (11 models), historical GHG only (20 models), historical natural only (20 models), and RCP8.5. Modeled trends are compared with 1901-2005 observed trends calculated from multiple datasets: GHCN, Climgrid, CRU, GPCC, and PRISM relative change for reference (vertical bars around trend values bound the $95 \%$ confidence intervals from 12-yr block bootstrapping; colored by dataset). Trends are quantified by taking the total percent change as calculated by a linear regression. In maps, dots indicate grid cells where greater than $75 \%$ of model simulations agree on the sign of the change.

southerly moisture transports into the SE-Gulf and observed SE-Gulf fall precipitation from a variety of datasets supports the practicality of using NCEP-NCAR for evaluating historical changes in atmospheric circulation along the western NASH. Further, the NCEP-NCAR trend toward an enhanced western NASH, as reflected by an enhanced zonal SLP gradient across the SEUS coast and Gulf of Mexico, is consistent with direct observations according to the Hadley Centre's gridded SLP dataset (Allan and Ansell 2006).

Historical changes in NASH intensity and position have been actively studied, but the vast majority of that research has focused on summer, when the NASH is strongest (L. Li et al. 2012; Li et al. 2011; Li et al. 2013; $\mathrm{Li}$ and Li 2015; W. Li et al. 2012; Diem 2013). In summer, a southwest displacement of the NASH western ridge and an intensification in the NASH central pressure have been linked to increased southerly moisture flux and resultant increases in summer precipitation in the SEUS (L. Li et al. 2012). Fall precipitation is nevertheless also sensitive to the NASH and the moisture transports it directs to the SEUS (Nigam et al. 2011). In an analysis of NASH variability in fall, Nigam et al. (2011) show that warm SSTs in the northern Atlantic (the AMO warm phase) weaken the NASH and suppress SEUS precipitation by reducing moisture transport from the Gulf of Mexico. Kushnir et al. (2010) indicate that warm North Atlantic SSTs suppress the NASH by inducing convection and weakening the subtropical low-level anticyclone in the NASH region. Less is known, however, about the causes of changes in NASH position during fall, which should also critically affect SEUS precipitation (L. Li et al. 2012).

The SST-forced atmospheric model simulations support the above point by suggesting that observed SSTs during 1901-2005 may have promoted enhanced fall anticyclonic atmospheric circulation around the western ridge of the NASH. This simulated enhancement occurs farther west than what was observed in reanalysis data and, as a result, the SST-forced simulations do not promote increased moisture transport into the SEUS from the Gulf of Mexico. Using a different atmospheric 

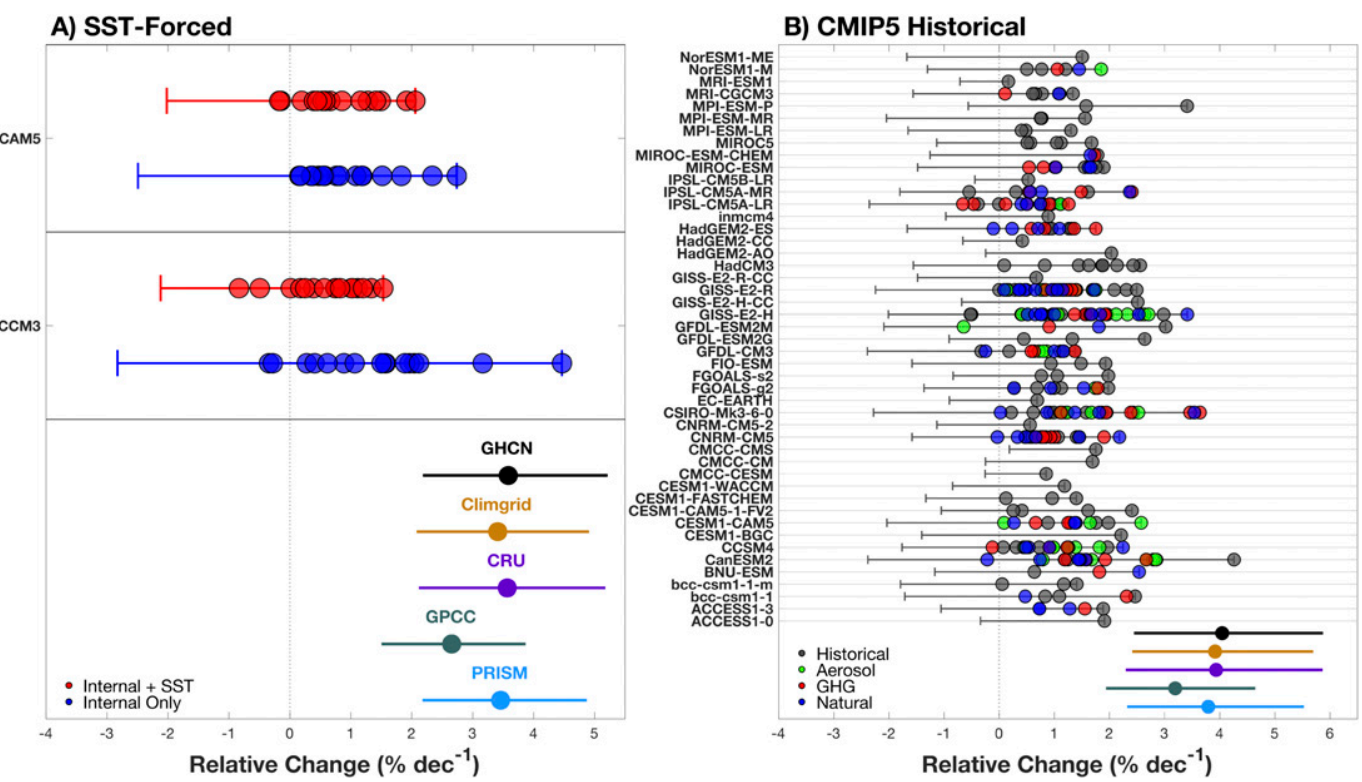

FIG. 8. Maximum simulated trends (relative change per decade) in fall SE-Gulf precipitation for (a) SST-forced and (b) CMIP5 historical simulations. Dots indicate maximum trend values among all (a) 115-yr [in (a)] and 105-yr [in (b)] periods in each model simulation, and horizontal bars span the full range of all simulated trends. Dots and bars at the bottom represent trends and 95\% confidence intervals from 12-yr block bootstrapping for the four observational datasets during 1901-2015 [in (a)] and 1901-2005 [in (b)]. Trends are quantified by taking the total percent change as calculated by a linear regression. In (a), blue dots indicate trends after the removal of each model's multisimulation mean to isolate trends caused by internal atmospheric variability.

model, Wang et al. (2009) did find that observed decadal variations in Pacific and Atlantic SSTs produce some fall wetting in the SEUS during 1950-2000, but these wetting patterns were weak and mostly focused west of the SEUS, consistent with the SST-forced simulations we evaluated. This western tendency in SST-forced models suggests that critical processes are missing from these simulations. One possible explanation is that the low resolution of the atmospheric models weakens the effects of topography and fine-resolution SST gradients on atmospheric circulation. Additionally, the SST-forced models' inability to simulate low-level circulation trends in the region suggest that ocean-atmosphere coupling, which the SST-forced models do not incorporate, may be critical for accurate simulation of SE-Gulf precipitation. Indeed, Seager et al. (2003) showed that without oceanatmosphere coupling, the subtropical anticyclones would be weaker than observed, which would dry the SE-Gulf. It is thus potentially problematic for simulations of SE-Gulf precipitation to use SST-forced simulations that only allow the atmosphere to respond to, but not influence, SSTs.

The fully coupled CMIP5 models tend to suggest that anthropogenic forcing weakly increased the likelihood of a twentieth-century fall wetting trend in the SE-Gulf, but individual simulations almost never produce trends as strong as those observed. These modeled wetting trends grow larger in simulations of future climate when subjected to stronger twenty-first-century anthropogenic forcing (RCP8.5). The proximate cause of the positive effect of anthropogenic forcing on SE-Gulf fall precipitation is through enhancement of the western ridge of the NASH, consistent with observations and SST-forced simulations. However, the CMIP5 ensemble-mean trends in historical circulation, like the ensemble-mean trends in SE-Gulf precipitation, are very weak. This suggests that observed SE-Gulf wetting was not strongly promoted by historical anthropogenic forcing. A caveat to these results, however, is that many of the coupled models used in the CMIP5 experiments do not accurately simulate observed relationships between SE-Gulf fall precipitation and global SST patterns.

Overall, model simulations suggest that the magnitude of the observed SE-Gulf fall wetting trend was extremely improbable, but processes that dictate the intensity and location of the western ridge of the NASH may not be well represented in these models (e.g., ocean-atmosphere coupling or global SST patterns). Moreover, natural ranges of low-frequency fall precipitation variability are not well simulated for the SE-Gulf. Importantly, model deficiencies are not easily explained by a clear inability to simulate the basic features of SE-Gulf precipitation climatology or large-scale 


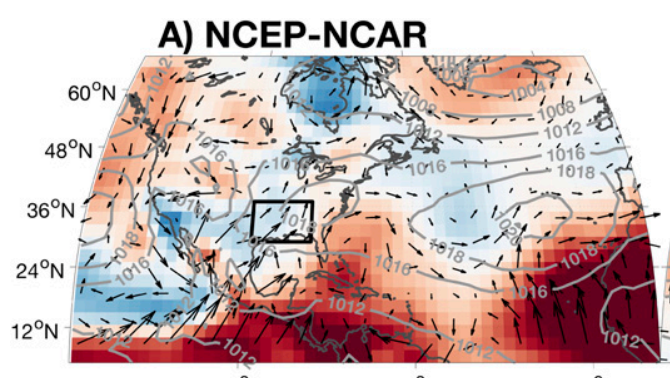

A) NCEP-NCAR

$100^{\circ} \mathrm{W}$

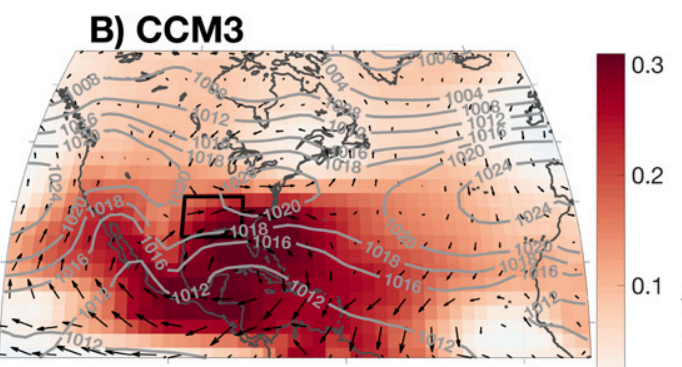

B) $\mathrm{CCM} 3$

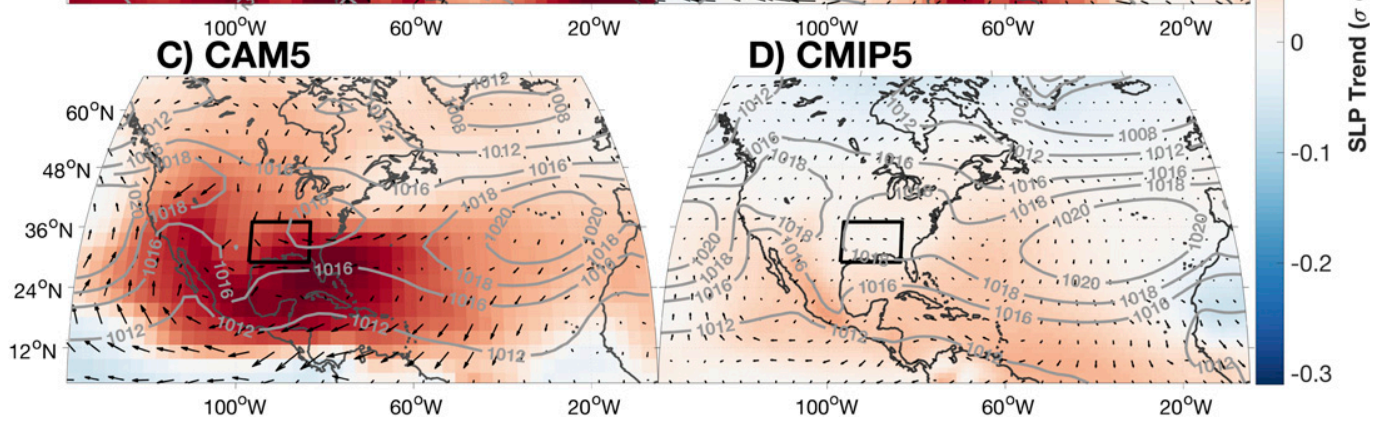

FIG. 9. The 1948-2005 trends in fall SLP (colors) and 850-hPa winds (arrows) for (a) NCEP-NCAR reanalysis and ensemble-mean (b) CCM3, (c) CAM5, and (d) CMIP5 historical simulations. Contours show climatological mean SLP. The black box bounds the SE-Gulf region.

dynamic drivers of interannual precipitation variability. In particular, the interannual relationship between atmospheric circulation around the western ridge of the NASH and SE-Gulf fall precipitation is well represented by models, suggesting that the models do have the capability to simulate a precipitation response to a trend in NASH position or intensity.

Future research should address why coupled models are unable to simulate the strength of observed correlations between SE-Gulf fall precipitation and large-scale SST patterns, and why SST-forced models simulate an enhanced circulation around the western ridge of the NASH substantially farther west than observed. In particular, modeled biases in SST and circulation may cause additional biases in how CMIP5-projected changes in the NASH affect SE-Gulf precipitation (e.g., Ryu and Hayhoe 2014; Liu et al. 2013). Further, future work to better elucidate the underlying drivers of changes in $\mathrm{NASH}$ position and intensity, particularly in the fall season, will be critical for informing expectations as to whether the observed fall wetting of the SE-Gulf over the past century will continue, level off, or reverse. This improved knowledge would also enrich understanding of past and future changes in precipitation in other NASH-sensitive regions, such as the Caribbean (Herrera and Ault 2017).

\section{Conclusions}

This work highlights an extreme increase in 1895-2016 precipitation of nearly $40 \%$ during the fall season in the
SEUS. The increase in precipitation is caused by increased moisture transport from the Gulf of Mexico and Caribbean as a result of enhanced wind velocity along the western ridge of the NASH. CMIP5 multimodel analyses suggest that historical GHG forcings may have increased the likelihood of wetting trends and future increases in GHGs are likely to provide further positive forcing to SE-Gulf precipitation totals. SST-forced atmospheric model simulations suggest this intensified circulation around the western NASH may have been influenced by changes in SSTs, but these models simulate the intensified circulation too far west and, as a result, do not simulate increased fall precipitation in the SEUS. The failure of SST-forced models to accurately simulate these features is likely influenced by model predisposition to simulate the atmosphere as an exclusive responder to SSTs. In reality, the atmosphere and ocean are tightly coupled, which is important to the general structure and strength of subtropical anticyclones. However, models that are fully coupled and forced by historical anthropogenic and/or natural radiative forcings also appear nearly, but not entirely, incapable of simulating increases in fall SEUS precipitation as large as those observed. However, given that coupled models tend to poorly represent observed relationships between SEUS fall precipitation and large-scale SST patterns, it appears possible that the precipitation increase was caused by processes not well represented in the coupled models. Observed trends over the past century indicate that multidecade variability in NASH circulation has profound 
impacts on how moisture is distributed across the eastern United States and adjacent areas. Continued research is necessary to better understand the drivers of changes in the NASH and whether the trends that drove large twentieth-century increases in SE-Gulf fall precipitation will continue, level off, or reverse in the coming decades.

Acknowledgments. This research was supported by the NASA Earth and Space Science Graduate Student Fellowship (80NSSC17K0402); the National Science Foundation (AGS-1703029 and AGS-1401400); the NASA Modeling, Analysis, and Prediction program (80NSSC17K0265); Columbia University's Center for Climate and Life; and a Lamont-Doherty Earth Observatory Postdoctoral Fellowship. We thank Edward Cook, Laifang Li, Matthew Newman, Sloan Coats, and four anonymous reviewers for feedback that improved the manuscript. We thank Sigfried Schubert and Hailan Wang (NASA GSFC) for making available the GEOS-5 model data, Naomi Henderson and Dong-Eun Lee for performing simulations with the NCAR SST-forced models, and Haibo Liu for assistance with CMIP data. This article is Lamont-Doherty Contribution Number 8273.

\section{REFERENCES}

Abatzoglou, J. T., and A. P. Williams, 2016: Impact of anthropogenic climate change on wildfire across western US forests. Proc. Natl. Acad. Sci. USA, 113, 11770-11775, https://doi.org/ 10.1073/pnas.1607171113.

Allan, R., and T. Ansell, 2006: A new globally complete monthly historical gridded mean sea level pressure dataset (HadSLP2): 1850-2004. J. Climate, 19, 5816-5842, https://doi.org/10.1175/ JCLI3937.1.

Arnell, N. W., 1999: Climate change and global water resources. Global Environ. Change, 9, S31-S49, https://doi.org/10.1016/ S0959-3780(99)00017-5.

Bishop, D. A., and N. Pederson, 2015: Regional variation of transient precipitation and rainless-day frequency across a subcontinental hydroclimate gradient. J. Extreme Events, 2, 1550007, https://doi.org/10.1142/S2345737615500074.

Clark, J. S., and Coauthors, 2016: The impacts of increasing drought on forest dynamics, structure, and biodiversity in the United States. Global Change Biol., 22, 2329-2352, https://doi.org/ 10.1111/gcb.13160.

Coats, S., J. E. Smerdon, K. B. Karnauskas, and R. Seager, 2016: The improbable but unexceptional occurrence of megadrought clustering in the American West during the Medieval Climate Anomaly. Environ. Res. Lett., 11, 074025, https://doi.org/ 10.1088/1748-9326/11/7/074025.

D'Orangeville, L., and Coauthors, 2018: Drought timing and local climate determine the sensitivity of eastern temperate forests to drought. Global Change Biol., 24, 2339-2351, https://doi.org/ 10.1111/gcb.14096.

Dai, A., 2011: Characteristics and trends in various forms of the Palmer Drought Severity Index during 1900-2008. J. Geophys. Res., 116, D12115, https://doi.org/10.1029/2010JD015541.
_ 2013: Increasing drought under global warming in observations and models. Nat. Climate Change, 3, 52-58, https://doi.org/ 10.1038/nclimate1633; Corrigendum, 3, 171, https://doi.org/ 10.1038/nclimate1811.

, and T. Zhao, 2017: Uncertainties in historical changes and future projections of drought. Part I: Estimates of historical drought changes. Climatic Change, 144, 519-533, https://doi.org/ 10.1007/s10584-016-1705-2.

— I. Y. Fung, and A. D. Del Genio, 1997: Surface observed global land precipitation variations during 1900-88. J. Climate, 10, 2943-2962, https://doi.org/10.1175/1520-0442(1997)010<2943: SOGLPV $>2.0 . \mathrm{CO} ; 2$.

Daly, C., M. Halblieb, J. I. Smith, W. P. Gibson, M. K. Doggett, G. H. Taylor, J. Curtis, and P. P. Pasteris, 2008: Physiographically sensitive mapping of climatological temperature and precipitation across the conterminous United States. Int. J. Climatol., 28, 2031-2064, https://doi.org/10.1002/ joc. 1688 .

Davis, R. E., B. P. Hayden, D. A. Gay, W. L. Phillips, and G. V. Jones, 1997: The North Atlantic subtropical anticyclone. J. Climate, 10, 728-744, https://doi.org/10.1175/1520-0442 (1997) $010<0728:$ TNASA $>2.0$. CO;2.

Deser, C., A. Phillips, V. Bourdette, and H. Teng, 2012: Uncertainty in climate change projections: The role of internal variability. Climate Dyn., 38, 527-546, https://doi.org/10.1007/ s00382-010-0977-x.

Diem, J. E., 2013: Influences of the Bermuda high and atmospheric moistening on changes in summer rainfall in the Atlanta, Georgia region, USA. Int. J. Climatol., 33, 160-172, https://doi. org/10.1002/joc.3421.

Easterling, D. R., and Coauthors, 2017: Precipitation change in the United States. Climate Science Special Report: Fourth National Climate Assessment, D. J. Wuebbles et al., Eds., Vol. I, U.S. Global Change Research Program, 207-230, https://doi.org/ 10.7930/J0H993CC.

Enfield, D. B., A. M. Mestas-Nuñez, and P. J. Trimble, 2001: The Atlantic multidecadal oscillation and its relation to rainfall and river flows in the continental U.S. Geophys. Res. Lett., 28 , 2077-2080, https://doi.org/10.1029/2000GL012745.

Godfray, H. C. J., and Coauthors, 2010: Food security: The challenge of feeding 9 billion people. Science, 327, 812-818, https:// doi.org/10.1126/science.1185383.

Harris, I., P. D. Jones, T. J. Osborn, and D. H. Lister, 2014: Updated high-resolution grids of monthly climatic observations-the CRU TS3.10 dataset. Int. J. Climatol., 34, 623-642, https://doi.org/ 10.1002/joc.3711.

Hartmann, D. L., and Coauthors, 2013: Observations: Atmosphere and surface. Climate Change 2013: The Physical Science Basis, T. F. Stocker et al., Eds., Cambridge University Press, 159-254, http://www.ipcc.ch/pdf/assessment-report/ar5/wg1/ WG1AR5_Chapter02_FINAL.pdf.

Henderson, K. G., and A. J. Vega, 1996: Regional precipitation variability in the southern United States. Phys. Geogr., 17, 93 112, https://doi.org/10.1080/02723646.1996.10642576.

Herrera, D., and T. Ault, 2017: Insights from a new high-resolution drought atlas for the Caribbean spanning 1950-2016. J. Climate, 30, 7801-7825, https://doi.org/10.1175/JCLI-D-16-0838.1.

Hurrell, J. W., 1995: Decadal trends in the North Atlantic Oscillation: Regional temperatures and precipitation. Science, $\mathbf{2 6 9}$, 676-679, https://doi.org/10.1126/science.269.5224.676.

Kalnay, E., and Coauthors, 1996: The NCEP/NCAR 40-Year Reanalysis Project. Bull. Amer. Meteor. Soc., 77, 437-471, https:// doi.org/10.1175/1520-0477(1996)077<0437:TNYRP >2.0.CO;2. 
Kaplan, A., M. A. Cane, Y. Kushnir, A. C. Clement, M. B. Blumenthal, and B. Rajagopalan, 1998: Analyses of global sea surface temperature 1856-1991. J. Geophys. Res., 103, $18567-$ 18 589, https://doi.org/10.1029/97JC01736.

Kiehl, J. T., J. J. Hack, G. B. Bonan, B. A. Boville, D. L. Williamson, and P. J. Rasch, 1998: The National Center for Atmospheric Research Community Climate Model: CCM3. J. Climate, 11, 1131-1149, https://doi.org/10.1175/1520-0442 (1998)011<1131:TNCFAR >2.0.CO;2.

Kushnir, Y., R. Seager, M. Ting, N. Naik, and J. Nakamura, 2010: Mechanisms of tropical Atlantic SST influence on North American precipitation variability. J. Climate, 23, 5610-5628, https://doi.org/10.1175/2010JCLI3172.1.

Li, L., and W. Li, 2015: Thermodynamic and dynamic contributions to future changes in regional precipitation variance: Focus on the southeastern United States. Climate Dyn., 45, 67-82, https://doi.org/10.1007/s00382-014-2216-3.

,,-- and Y. Kushnir, 2012: Variation of the North Atlantic subtropical high western ridge and its implication to southeastern US summer precipitation. Climate Dyn., 39, 14011412, https://doi.org/10.1007/s00382-011-1214-y.

,$- \ldots$, and A. P. Barros, 2013: Atmospheric moisture budget and its regulation of the summer precipitation variability over the southeastern United States. Climate Dyn., 41, 613-631, https://doi.org/10.1007/s00382-013-1697-9.

Li, W., L. Li, R. Fu, Y. Deng, and H. Wang, 2011: Changes to the North Atlantic subtropical high and its role in the intensification of summer rainfall variability in the southeastern United States. J. Climate, 24, 1499-1506, https://doi.org/ 10.1175/2010JCLI3829.1.

,,-- M. Ting, and Y. Liu, 2012: Intensification of Northern Hemisphere subtropical highs in a warming climate. Nat. Geosci., 5, 830-834, https://doi.org/10.1038/ngeo1590.

Liu, H., C. Wang, S.-K. Lee, and D. Enfield, 2013: Atlantic warm pool variability in the CMIP5 simulations. J. Climate, 26, 53155336, https://doi.org/10.1175/JCLI-D-12-00556.1.

Menne, M. J., C. N. Williams Jr., and R. S. Vose, 2009: The U.S. Historical Climatology Network monthly temperature data, version 2. Bull. Amer. Meteor. Soc., 90, 993-1007, https://doi.org/ 10.1175/2008BAMS2613.1.

_ , and Coauthors, 2012: Global Historical Climatology NetworkDaily (GHCN-Daily), version 3. NOAA National Climatic Data Center, accessed 13 March 2018, https://doi.org/10.7289/ V5D21VHZ.

Mo, K. C., 2010: Interdecadal modulation of the impact of ENSO on precipitation and temperature over the United States. J. Climate, 23, 3639-3656, https://doi.org/10.1175/ 2010JCLI3553.1.

Neale, R. B., and Coauthors, 2012: Description of the NCAR Community Atmosphere Model (CAM 5.0). NCAR Tech. Note NCAR/TN-486+STR, 274 pp., www.cesm.ucar.edu/ models/cesm1.0/cam/docs/description/cam5_desc.pdf.

Nigam, S., B. Guan, and A. Ruiz-Barradas, 2011: Key role of the Atlantic multidecadal oscillation in 20th century drought and wet periods over the Great Plains. Geophys. Res. Lett., 38 , L16713, https://doi.org/10.1029/2011GL048650.

Pederson, N., A. R. Bell, E. R. Cook, U. Lall, N. Devineni, R. Seager, K. Eggleston, and K. P. Vranes, 2013: Is an epic pluvial masking the water insecurity of the greater New York City region? J. Climate, 26, 1339-1354, https://doi.org/10.1175/ JCLI-D-11-00723.1.

Pettitt, A. N., 1979: A non-parametric approach to the changepoint problem. Appl. Stat., 28C, 126-135.
Qian, T., A. Dai, and K. E. Trenberth, 2007: Hydroclimatic trends in the Mississippi River basin from 1948 to 2004. J. Climate, 20, 4599-4614, https://doi.org/10.1175/JCLI4262.1.

Rayner, N. A., D. E. Parker, E. B. Horton, C. K. Folland, L. V. Alexander, D. P. Rowell, E. C. Kent, and A. Kaplan, 2003: Global analyses of sea surface temperature, sea ice, and night marine air temperature since the late nineteenth century. J. Geophys. Res., 108, 4407, https://doi.org/10.1029/ 2002JD002670.

Riahi, K., and Coauthors, 2011: RCP 8.5-A scenario of comparatively high greenhouse gas emissions. Climatic Change, 109, 33-57, https://doi.org/10.1007/s10584-011-0149-y.

Ryu, J.-H., and K. Hayhoe, 2014: Understanding the sources of Caribbean precipitation biases in CMIP3 and CMIP5 simulations. Climate Dyn., 42, 3233-3252, https://doi.org/10.1007/ s00382-013-1801-1.

Schmidhuber, J., and F. N. Tubiello, 2007: Global food security under climate change. Proc. Natl. Acad. Sci. USA, 104, 19703 19708, https://doi.org/10.1073/pnas.0701976104.

Schneider, U., A. Becker, P. Finger, A. Meyer-Christoffer, and M. Ziese, 2018: GPCC full data monthly product at $0.5^{\circ}$ : Monthly land-surface precipitation from rain-gauges built on GTS-based and historical data, version 2018. Deutscher Wetterdienst, accessed 13 March 2018, https://doi.org/10.5676/ DWD_GPCC/FD_M_V2018_050.

Schreiber, T., and A. Schmitz, 2000: Surrogate time series. Physica $D$, 142, 346-382, https://doi.org/10.1016/S0167-2789(00)00043-9.

Seager, R., R. Murtugudde, N. Naik, A. Clement, N. Gordon, and J. Miller, 2003: Air-sea interaction and the seasonal cycle of the subtropical anticyclones. J. Climate, 16, 1948-1966, https://doi.org/ 10.1175/1520-0442(2003)016<1948:AIATSC >2.0.CO;2.

, Y. Kushnir, C. Herweijer, N. Naik, and J. Velez, 2005: Modeling of tropical forcing of persistent droughts and pluvials over western North America: 1856-2000. J. Climate, 18, 4065-4088, https://doi.org/10.1175/JCLI3522.1.

— N N. Pederson, Y. Kushnir, J. Nakamura, and S. Jurburg, 2012: The 1960s drought and the subsequent shift to a wetter climate in the Catskill Mountains region of the New York City watershed. J. Climate, 25, 6721-6742, https://doi.org/10.1175/ JCLI-D-11-00518.1.

— , and Coauthors, 2014: Dynamical and thermodynamical causes of large-scale changes in the hydrological cycle over North America in response to global warming. J. Climate, 27, 7921-7948, https://doi.org/10.1175/JCLI-D-14-00153.1.

, M. Hoerling, S. Schubert, H. Wang, B. Lyon, A. Kumar, J. Nakamura, and N. Henderson, 2015: Causes of the 2011-14 California drought. J. Climate, 28, 6997-7024, https://doi.org/ 10.1175/JCLI-D-14-00860.1.

Shaw, T. A., and O. Pauluis, 2012: Tropical and subtropical meridional latent heat transports by disturbances to the zonal mean and their role in the general circulation. J. Atmos. Sci., 69, 1872-1889, https://doi.org/10.1175/JAS-D-11-0236.1.

Sheffield, J., E. F. Wood, and M. L. Roderick, 2012: Little change in global drought over the past 60 years. Nature, 491, 435-440, https://doi.org/10.1038/nature11575.

Small, D., S. Islam, and R. M. Vogel, 2006: Trends in precipitation and streamflow in the eastern U.S.: Paradox or perception? Geophys. Res. Lett., 33, L03403, https://doi.org/10.1029/ 2005 GL024995.

Taylor, K. E., R. J. Stouffer, and G. A. Meehl, 2012: An overview of CMIP5 and the experiment design. Bull. Amer. Meteor. Soc., 93, 485-498, https://doi.org/10.1175/BAMSD-11-00094.1. 
van Vuuren, D. P., and Coauthors, 2011: The representative concentration pathways: An overview. Climatic Change, 109, 5-31, https://doi.org/10.1007/s10584-011-0148-z.

Villarini, G., F. Serinaldi, J. A. Smith, and W. F. Krajewski, 2009: On the stationarity of annual flood peaks in the continental United States during the 20th century. Water Resour. Res., 45, W08417, https://doi.org/10.1029/ 2008WR007645.

Visbeck, M. H., J. W. Hurrell, L. Polvani, and H. M. Cullen, 2001: The North Atlantic Oscillation: Past, present, and future. Proc. Natl. Acad. Sci. USA, 98, 12876-12877, https://doi.org/ 10.1073/pnas.231391598.

Vose, R. S., and Coauthors, 2014: Improved historical temperature and precipitation time series for U.S. climate divisions. J. Appl. Meteor. Climatol., 53, 1232-1251, https://doi.org/ 10.1175/JAMC-D-13-0248.1.

Wang, H., S. Schubert, M. Suarez, J. Chen, M. Hoerling, A. Kumar, and P. Pegion, 2009: Attribution of the seasonality and regionality in climate trends over the United States during 1950-2000. J. Climate, 22, 2571-2590, https://doi.org/10.1175/2008JCLI2359.1.

Weaver, S. J., and S. Nigam, 2008: Variability of the Great Plains low-level jet: Large-scale circulation context and hydroclimate impacts. J. Climate, 21, 1532-1551, https://doi.org/10.1175/ 2007JCLI1586.1.

Westerling, A. L., 2016: Increasing western US forest wildfire activity: Sensitivity to changes in the timing of spring. Philos. Trans. Roy. Soc. London, 371B, 20150178, https://doi.org/ 10.1098/rstb.2015.0178.

Williams, A. P., B. I. Cook, J. E. Smerdon, D. A. Bishop, R. Seager, and J. S. Mankin, 2017: The 2016 southeastern U.S. drought: An extreme departure from centennial wetting and cooling. J. Geophys. Res. Atmos., 122, 10888-10905, https://doi.org/ 10.1002/2017JD027523.

Zhu, Z., and Coauthors, 2016: Greening of the Earth and its drivers. Nat. Climate Change, 6, 791-795, https://doi.org/ 10.1038/nclimate3004. 